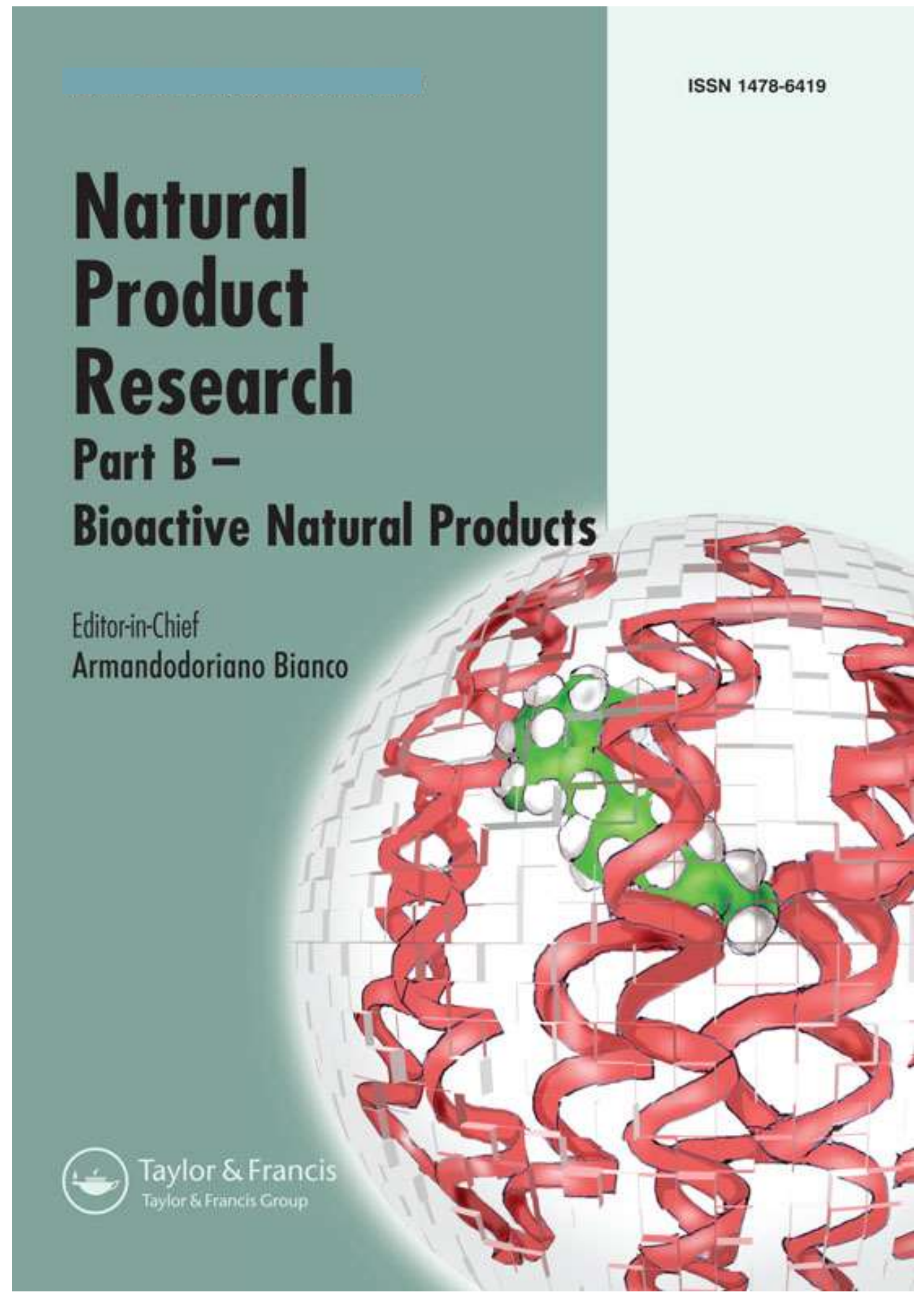




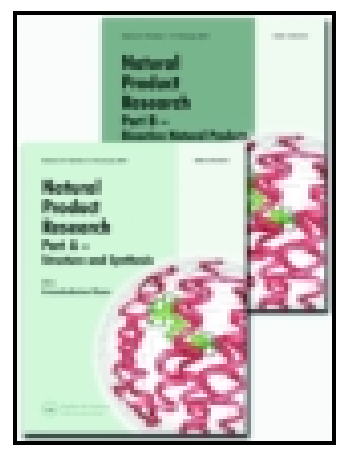

Natural Product Research

Formerly Natural Product Letters

ISSN: 1478-6419 (Print) 1478-6427 (Online) Journal homepage: https://www.tandfonline.com/loi/gnpl20

\section{A new pyrano coumarin from Clausena excavata roots displaying dual inhibition against $\alpha$ - glucosidase and free radical}

Tin Myo Thant, Nanik Siti Aminah, Alfinda Novi Kristanti, Rico Ramadhan, Preecha Phuwapraisirisan \& Yoshiaki Takaya

To cite this article: Tin Myo Thant, Nanik Siti Aminah, Alfinda Novi Kristanti, Rico Ramadhan, Preecha Phuwapraisirisan \& Yoshiaki Takaya (2019): A new pyrano coumarin from Clausena excavata roots displaying dual inhibition against $\alpha$-glucosidase and free radical, Natural Product Research, DOI: 10.1080/14786419.2019.1586696

To link to this article: https://doi.org/10.1080/14786419.2019.1586696

View supplementary material \lceil

Published online: 25 Mar 2019.

Submit your article to this journal $\asymp$

Џ Article views: 12

View Crossmark data $₫$ 


\title{
A new pyrano coumarin from Clausena excavata roots displaying dual inhibition against $\alpha$-glucosidase and free radical
}

\author{
Tin Myo Thant ${ }^{a, b}$ (D), Nanik Siti Aminah ${ }^{a}$ (D), Alfinda Novi Kristanti ${ }^{a}$ (D), \\ Rico Ramadhan ${ }^{\mathrm{a}}$ (D), Preecha Phuwapraisirisan ${ }^{\mathrm{c}}$ (D) and Yoshiaki Takaya ${ }^{\mathrm{d}}$ \\ ${ }^{a}$ Department of Chemistry, Faculty of Science and Technology, Universitas Airlangga, Komplek \\ Kampus C UNAIR, Jl, Mulyorejo, Surabaya, Indonesia; ${ }^{b}$ Department of Chemistry, Kyaukse University, \\ Kyaukse Township, Myanmar; 'Center of Excellence in Natural Products, Department of Chemistry,

 \\ Tempaku, Nagoya, Japan
}

\section{ABSTRACT}

A new pyrano coumarin, identified as excavatin A (1) together with two known compounds nordentatin (2) and binorpocitrin (3) was isolated from the $95 \% \mathrm{EtOH}$ extract of Clausena excavata. All structures were elucidated by using spectroscopy methods such as extensive NMR and HR-FAB-MS spectrometry. All the isolated compounds were tested on antidiabetes activity by using $\alpha$-glucosidase inhibition assay and the antioxidant activity by DPPH assay. Compounds 1-3 showed antioxidant activity with $I C_{50}$ values $0.286,0.02,0.278 \mathrm{mM}$. Among them, 2 exhibited inhibition activity against maltase ( $\left(\mathrm{IC}_{50} 5.45 \mu \mathrm{M}\right)$ and sucrase $\left(\mathrm{IC}_{50} \quad 43.57 \mu \mathrm{M}\right)$. However, compounds (1) and (3) displayed inhibition on yeast $\alpha$-glucosidase with $\mathrm{IC}_{50}$ values 1.92 and $5.58 \mathrm{mM}$.

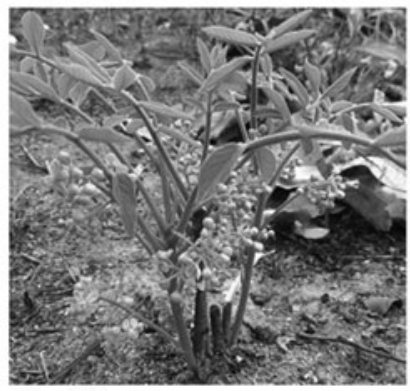<smiles>C=CC(C)(C)c1c2c(c3oc(=O)c(C(C)(C)C=C)cc3c1O)C=CC(C)(C)O2</smiles>

excavatin A (1)

\section{ARTICLE HISTORY}

Received 8 November 2018 Accepted 20 February 2019

\section{KEYWORDS}

Clausena excavata; pyrano coumarin; inhibition; $\alpha$-glycosidase; antioxidant; IC50

Clausena excavata

\section{Introduction}

Diabetes mellitus (DM) is the common endocrinal disorder and rapidly increasing disease in the human population all over the world. The numbers concerning the

CONTACT Nanik Siti Aminah nanik-s-a@fst.unair.ac.id

(1) Supplemental data for this article can be accessed at https://doi.org/10.1080/14786419.2019.1586696.

(C) 2019 Informa UK Limited, trading as Taylor \& Francis Group 
prevalence of DM are alarming; about 415 million people worldwide are estimated to have diabetes, expected that the numbers will rise to 642 million or more diabetic patients in 2040 (Gothai et al. 2016). Diabetes Mellitus can be classified into clinical categories as: Type 1 Diabetes (T1DM), caused by $\beta$-cell destruction and usually leading to absolute insulin deficiency, Type 2 Diabetes (T2DM), due to a defect on the background of insulin resistance, and others such as gestational diabetes and specific types such as monogenic diabetes syndromes, exocrine pancreas diseases, and drug or chemical-induced diabetes (Deepak et al. 2014; Munhoz and Frode 2018). Although obesity and physical inactivity are known to be major risk factors for type 2 diabetes (T2DM), recent evidence suggests that oxidative stress may contribute to the pathogenesis of T2DM by increasing insulin resistance or impairing insulin secretion (Bajaj and Khan 2012). Various studies have shown that diabetes mellitus is associated with increased formation of free radicals and decreases antioxidant potential which, leads to disturbances in the balance between radical formation and protection against which ultimately results in oxidative damage of cell components such as proteins, lipids, and nucleic acids. An increased oxidative stress can be observed in both insulindependent (type 1) and non-insulin-dependent diabetes (type 2) (Sindhi et al. 2013). Type 2 diabetes is the predominant form of diabetes and accounts for at least $90 \%$ of all cases of diabetes. One of the established therapeutics to treat type 2 diabetes is to control blood glucose levels after eating. Decreased blood glucose levels after eating can be done with delaying the absorption of glucose by inhibiting the enzyme $\alpha$-glucosidase activity (Cahyani and Purwaningsih 2015). In recent years, some of the standard synthetic drugs used for the treatment of diabetes lead to cause side effects like nausea, vomiting, abdominal pain, diarrhoea, head ache, abnormal weight gain, allergic reaction, low blood glucose, dark urine, fluid retention or swelling. Moreover, they are not safe for use during pregnancy. Active research has been performed on traditional available medicinal plants for discovery of new antidiabetic drug as an alternative for synthetic drugs (Abirami et al. 2014).

The genus Clausena belongs to the Rutaceae family, comprises of about 14 species of evergreen trees (Arbab et al. 2013). C. excavata is one the most well-known species in genus Clausena, is a shrub with strong and rather objectionable smell, found from the Himalayas and China to and throughout Southeast Asia (Taufiq-Yap et al. 2007). In Myanmar, it is locally known as 'Sat pu Kharyar', 'Taw Pyin Daw Thein'. People in Myanmar usually used this plant to treat headache, itching, flu, snake-bite detoxification. Clausena spp. is an abundant source of secondary metabolites, especially carbazole alkaloids, coumarins (furano and pyrano) and few lemonoids (Wu et al. 1999; Ito et al. 2000, Kumar et al. 2012; Liu et al. 2018). Many pharmacologically active compounds isolated from Clausena species have been used for the treatment of human diseases such as cardiovascular disease, anti-inflammatory, antioxidants, anti-snake venom, anticancer, anti-HIV, and antiplatelet (Auranwiwat et al. 2014; Arbab et al. 2015; Chakthong et al. 2016; Ma et al. 2017). In addition, Clausena species has been found to possess anti-diabetic activity (Damsud et al. 2017). The current research is conducted to isolate bioactive antidiabetic and antioxidant compounds from the roots of $C$. excavata. A new pyrano coumarin (1), excavatin A along with two pyrano coumarin, nordentatin (2), binorpocitrin (3) was isolated. Based on our knowledge, there was 
not yet reported on $\alpha$-glucosidase inhibitory activity and antioxidant activity of these isolated compounds. So we conducted to these bioactive compounds on $\alpha$-glucosidase inhibition activity by using yeast and rat intestinal (maltase, sucrose) enzymes and antioxidant activity was performed by DPPH assay.

\section{Results and discussion}

The excavatin-A (1) was obtained as a colorless crystal with melting point $261-262^{\circ} \mathrm{C}$ and it was assigned the molecular formula, $\mathrm{C}_{24} \mathrm{H}_{28} \mathrm{O}_{4}$, as deduced from the positive HR-FAB-MS at $\mathrm{m} / \mathrm{z} 381.2058\left[\mathrm{M}^{+} \mathrm{H}\right]^{+}$(calcd for $\mathrm{C}_{24} \mathrm{H}_{28} \mathrm{O}_{4}, 381.2066$ ). The IR spectrum indicated the presence of hydroxyl $\left(3174 \mathrm{~cm}^{-1}\right)$, conjugated lactone $\left(1670 \mathrm{~cm}^{-1}\right)$ and aromatic $\left(1608,1591,1469 \mathrm{~cm}^{-1}\right)$ groups. The UV spectrum showed absorption maxima at 335, 278 and $227 \mathrm{~nm}$ due to 7-oxygenated coumarin.

The ${ }^{1} \mathrm{H}$ NMR spectrum (Table S1) displayed the presence of pyrone substituted coumarin was revealed by the aromatic singlet proton at $\delta_{\mathrm{H}} 7.90(1 \mathrm{H}, \mathrm{s}, \mathrm{H}-4)$. The existence of olefinic protons of chromene ring was indicated by two peaks at $\delta_{\mathrm{H}}$ $6.56(1 \mathrm{H}, \mathrm{d}, J=9.9 \mathrm{~Hz}, \mathrm{H}-9)$ and $\delta_{\mathrm{H}} 5.66(1 \mathrm{H}, \mathrm{d}, J=9.9 \mathrm{~Hz}, \mathrm{H}-10)$ respectively. The existence of two pairs of exomethylene protons was displayed at $\delta_{\mathrm{H}} 6.18(1 \mathrm{H}, \mathrm{dd}, J=16.5$, $\left.10.6 \mathrm{~Hz}, \mathrm{H}-2^{\prime}\right)$ and $5.08\left(1 \mathrm{H}, \mathrm{dd}, J=16.5,1.2 \mathrm{~Hz}, \mathrm{H}-3^{\prime} \mathrm{a}\right), 5.06\left(1 \mathrm{H}, \mathrm{dd}, J=1.2,10.6 \mathrm{~Hz}, \mathrm{H}-3^{\prime} \mathrm{a}\right)$ and another attached to C-6 was revealed 1,1-dimethyl group at $\delta_{\mathrm{H}} 6.29(1 \mathrm{H}$, dd, $\left.J=17.4,10.6 \mathrm{~Hz}, \mathrm{H}-2^{\prime \prime}\right), 4.92\left(1 \mathrm{H}, \mathrm{dd}, J=17.4,1.1 \mathrm{~Hz}, \mathrm{H}-3 \mathrm{a}^{\prime \prime}\right) 4.85(1 \mathrm{H}, \mathrm{dd}, J=10.6$, $\left.1.2 \mathrm{~Hz}, \mathrm{H}-3 \mathrm{~b}^{\prime \prime}\right)$. At the aliphatic regions 3 pairs of 1,1 dimethyl group showed three singlets at $\delta_{\mathrm{H}} 1.42(\mathrm{~s}, 6 \mathrm{H}, \mathrm{H}-11 \mathrm{a}, \mathrm{H}-11 \mathrm{~b}), 1.47\left(\mathrm{~s}, 6 \mathrm{H}, \mathrm{H}-1 \mathrm{a}^{\prime}\right.$ and $\left.1 \mathrm{~b}^{\prime}\right), 1.63\left(\mathrm{~s}, 6 \mathrm{H}, \mathrm{H}-1 \mathrm{a}^{\prime \prime}\right.$ and $1 \mathrm{~b}^{\prime \prime}$ ) (Table $\mathrm{S} 1$ ). The ${ }^{13} \mathrm{C}$-NMR spectrum of compound (1) indicated the presence of one cyclic lactone carbonyl carbon, five $\mathrm{sp}^{2}$ and three $\mathrm{sp}^{3}$ quaternary carbons, five methane carbons, two exomethylene carbons and six methyl carbons (Table S1). The $2 \mathrm{D} \mathrm{NMR}, \mathrm{DQF}-\mathrm{COSY}$ spectrum displayed the adjacent proton-proton correlation of three sets of proton pairs $\delta_{\mathrm{H}} 6.56(\mathrm{H}-9)$ and $\delta_{\mathrm{H}} 5.66(\mathrm{H}-10), \delta_{\mathrm{H}} 6.18(1 \mathrm{H}, \mathrm{dd}, J=16.5,10$. $\left.6 \mathrm{~Hz}, \mathrm{H}-2^{\prime}\right)$ and 5.08(H-3'a), 5.06(H-3'a), $\delta_{\mathrm{H}} 6.29\left(\mathrm{H}-2^{\prime \prime}\right)$ and $4.92\left(\mathrm{H}-3 \mathrm{a}^{\prime \prime}\right) 4.85\left(\mathrm{H}-3 \mathrm{~b}^{\prime \prime}\right)$ (figure S1). The inter-correlation of basic coumarin with chromene ring and two prenyl groups were confirmed by ${ }^{1} \mathrm{H}-{ }^{13} \mathrm{C}$ long range coupling of $\mathrm{HMBC}$ spectrum (Figure S6). The HMBC spectrum of compound (1) showed some correlation between $\mathrm{H}-4 / \mathrm{C}-\mathrm{I}^{\prime}$, $\mathrm{C}-2, \mathrm{C}-3, \mathrm{C}-5, \mathrm{C}-8 \mathrm{a}$. It was revealed that the pyrone substituted coumarin with the position of $\mathrm{H}-4$ proton and the prenyl group that attached to $\mathrm{C}-3$ carbon of pyrone ring. Another prenyl group proton $\mathrm{H}-1 \mathrm{a}^{\prime \prime}, 1 \mathrm{~b}^{\prime \prime} / \mathrm{C}-1^{\prime \prime}, \mathrm{C}-2^{\prime \prime}, \mathrm{C}-6$ revealed the attachment of prenyl to C-6 position of core coumarin. ${ }^{1} \mathrm{H}-\mathrm{NMR}$ and ${ }^{13} \mathrm{C}-\mathrm{NMR}$ of compound (1) is similar with clausarin that chromene ring was attached to core coumarin linearly. But in the HMBC spectrum of compound (1) strong correlation between $\mathrm{H}-9$ ( $\delta 6.56)$ to C$8(\delta$ 106.0), $\mathrm{C}-8 \mathrm{a}(\delta 146.5)$ and $\mathrm{C}-7(\delta$ 154.9) by HMBC spectrum (Figure S6) (Figure S1) showed that chromene ring was angularly connected to core coumarin (Takemura et al. 1996). Moreover, clausarin has to showed correlation between $\mathrm{H}-11(\delta 6.56 \mathrm{~Hz})$ with $\mathrm{C}-6(115.4 \mathrm{~Hz})$. The correlation was not found in compound (1) (Table S1, figure S6). So it is showed that the structure is more reliable to compound (1). The NOESY spectrum of (1) showed the cross-peak of $\mathrm{H}-4$ proton with 1,1 dimethyl protons $\mathrm{H}-1 \mathrm{a}^{\prime}$ and $1 b^{\prime}$ and exomethylene protons $\mathrm{H}-1^{\prime}$. Another cross peak displayed $\mathrm{H}-10$ to $\mathrm{H}-9$, 


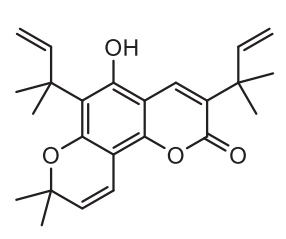

1

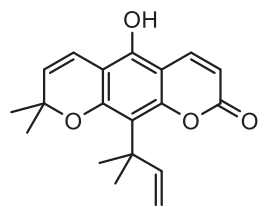

2

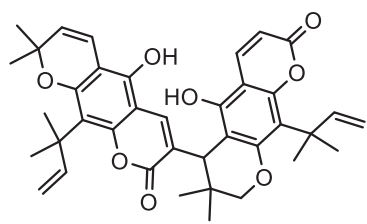

3

Figure 1. Structures of isolated compounds from C. excavata.

Table 1. $\alpha$-glucosidase inhibitory activities of isolated compounds (1-3).

\begin{tabular}{lcccc}
\hline & \multicolumn{3}{c}{$\alpha$-Glucosidase } & \\
\cline { 2 - 4 } Compound & Baker's yeast $\mathrm{IC}_{50}(\mathrm{mM})$ & Maltase $\mathrm{IC}_{50}(\mu \mathrm{M})^{*}$ & Sucrase $\mathrm{IC}_{50}(\mu \mathrm{M})^{*}$ & $\mathrm{DPPH} \mathrm{IC}_{50}(\mathrm{mM})$ \\
\hline 1 & 1.92 & $\mathrm{NI}$ & $\mathrm{NI}$ & 0.286 \\
2 & 37.62 & 5.45 & 43.57 & 0.02 \\
3 & 5.58 & $\mathrm{NI}$ & $\mathrm{NI}$ & 0.278 \\
Acarbose & 0.1030 & 2.35 & 15.48 & - \\
Ascorbic acid & - & - & - & 0.0118 \\
\hline
\end{tabular}

*Nonlinear regression analyzes were evaluated by SigmaPlot 12.5 .

$\mathrm{H}-11 \mathrm{a}, \mathrm{H}-11 \mathrm{~b}$ and $\mathrm{H} 2^{\prime \prime}$ to $\mathrm{H}-1 \mathrm{a}^{\prime \prime}, \mathrm{H}-1 \mathrm{~b}^{\prime \prime}, \mathrm{H}-3^{\prime \prime}$. Hence the structure of compound (1) was unambiguously elucidated to be 5-hydroxy-8,8-dimethyl-3,6-bis(2-methylbut-3-en-2-yl)$2 \mathrm{H}, 8 \mathrm{H}$-pyrano[2,3-f]chromen-2-one (Figure 1).

By analysis of the physicochemical properties, NMR, and MS data, and comparison with those reported in the literature, the two known compounds were identified as pyrano coumarin, namely, nordentatin (2) and binorpocitrin (3) (Sripisut et al. 2012). All compounds were further evaluated for their inhibitory effects against $\alpha$-glucosidase such as baker's yeast and rat intestinal (maltase and sucrose) $\alpha$-glucosidase and antioxidant activity were measured by DPPH assay (Table 1). All compounds 1-3 exhibited radical scavenging activity with $\mathrm{IC}_{50}$ values $0.286,0.02,0.278 \mathrm{mM}$ and displayed against sucrase with $\mathrm{IC}_{50}$ values $1.92,37.62$ and $5.58 \mathrm{mM}$ respectively. However, in maltase $\alpha$ - glucosidase assay nordentatin (2) showed inhibition $5.45 \mu \mathrm{M}$ but compound 1 and 3 showed no inhibition.

\section{Experimental}

\subsection{Plant material}

The roots of $C$. excavata were collected from Pyin Ma Nar Township, Mandalay Division, Myanmar in October 2016. The plant materials were authenticated by Prof. Soe Myint Aye, botanist from Department of Botany, Mandalay University, Myanmar, where the voucher specimen (UM-22032018) was deposited.

\subsection{Extraction and isolation}

The dried roots $(3.6 \mathrm{~kg}$ ) were extracted successively with $95 \% \mathrm{EtOH}(12.0 \mathrm{~L})$ over a period of two weeks at room temperature. Removal of the solvent under reduce pressure gave $156 \mathrm{~g}$ of dark gummy extracts. The extract $(100 \mathrm{~g})$ was partitioned three times using solvents; $n$-hex: methanol $(1: 1, v / v)$ successfully. Then methanol portion $(80.4 \mathrm{~g})$ was fractionationated by vacuum liquid chromatography over silica gel eluted 
with different mixtures of $n$-hex: EtOAc by stepwise increasing gradient polarity gave a total of 7 combined fractions (MF-1 to -7) were obtained. Among them the pale yellow crystals were come out from the combine fraction MF-5. After washing with ethyl acetate the pure compound nordentatin $(2,2.1 \mathrm{~g})$ was afforded. The sub fraction MF-2 was fractionated by silica gel column eluting with gradient polarity $n$-hex: EtOAc, $(0-10 \%$ EtOAc) afforded new compound, excavatin A (1, $68 \mathrm{mg})$. The fraction MF-6 (25.6 g) was subjected to VLC chromatography with $n$-hex:EtOAc (EtOAc, 10-100\%) with gradient polarity and afforded 23 subfraction and after combining same component fractions gave (MF-6.1 to 6.7). Fraction MF-6.2 (3.4 g) was subjected to silica gel column chroma-

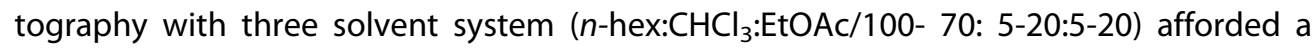
total of 300 fractions. White amorphous solid was come out from 201-215 and yielded pure compound, binorponcitrin (3,138 mg).

Excavatin A, colorless crystal, mp. $261-262^{\circ} \mathrm{C}$; UV (MeOH), $\lambda_{\max }(\log \varepsilon) 335$ (1.23), 279 (2.08), 228 (1.53). FT-IR (KBr) cm $\mathrm{cm}^{-1}:$ 3174, 2968, 1670, 1608, 1591, 1570, 1465, 1379, 1340, 1186, 1147, 1026, 908, 891. ${ }^{1} \mathrm{H}$ NMR and ${ }^{13} \mathrm{C}$ NMR data see (Table S1), HR-FABMS $\left(m / z\left[\mathrm{M}^{+}\right] \mathrm{H}^{+}\right)$381.2058, (calcd for $\mathrm{C}_{24} \mathrm{H}_{28} \mathrm{O}_{4}, 381.2066$ ).

\section{Conclusion}

In summary, three compounds were isolated from Myanmar medicinal plant C. excavata including a new pyrone substituted coumarin (1) together with two known bioactive compounds (2-3). The examination of all isolated compounds was done on antidiabetes activity by using $\alpha$-glucosidase inhibition assay and the antioxidant activity was conducted by DPPH assay. Of isolated compounds, $\mathbf{2}$ exhibited inhibition activity against maltase $\left(\mathrm{IC}_{50} 5.45 \mu \mathrm{M}\right)$ and sucrase $\left(\mathrm{IC}_{50} 43.57 \mu \mathrm{M}\right)$ respectively. However, compounds (1) and (3) displayed inhibition on yeast $\alpha$-glucosidase with $I_{50}$ values 1.92 , and $5.58 \mathrm{mM}$. Moreover, all isolated compounds showed high antioxidant activity with $\mathrm{IC}_{50}$ values values $0.286,0.02,0.278 \mathrm{mM}$ respectively. According recent study, isolated components from root of $C$. excavata can be candidate of natural antidiabetes and antioxidant.

\section{Acknowledgement}

T.M.T. would like to thank Universitas Airlangga, Directorate General of Higher Education (DIKTI), Ministry of Education and Culture of Indonesia that has funded this research.

\section{Disclosure statement}

No potential conflict of interest was reported by the authors.

\section{ORCID}

Tin Myo Thant (D) http://orcid.org/0000-0002-0445-1867

Nanik Siti Aminah (D) http://orcid.org/0000-0002-2767-6006

Alfinda Novi Kristanti (DD http://orcid.org/0000-0002-3023-7098

Rico Ramadhan (D) http://orcid.org/0000-0002-2565-7944

Preecha Phuwapraisirisan (ID http://orcid.org/0000-0001-6481-7712 


\section{References}

Abirami N, Natarajan B, Sagadevan E. 2014. Phytochemical investigation and in vitro evaluation of hypoglycemic potential of Grewia hirsuta. Int J Pharma Bio Sci. 5:76-83.

Arbab IA, Abdul AB, Sukari MA, Abdullah R, Syam S, Kamalidehghan B, Ibrahim MY, Taha MME, Abdelwahab SI, Ali HM, et al. 2013. Dentatin isolated from Clausena excavata induces apoptosis in MCF-7 cells through the intrinsic pathway with involvement of NF- $\kappa B$ signalling and G0/G1 cell cycle arrest: A bioassay-guided approach. J Ethnopharmacol. 145(1):343-354.

Arbab IA, Sani NA, Ibrahim MY, Abdalla B, Abdelwahab SI. 2015. Dentatin from Clausena excavata induces apoptosis and reduces the tumors size of La-7 induced mammary carcinogenesis in Sprague Dawley rats. Int J Adv Multidis Res. 2:67-73.

Auranwiwat C, Laphookhieo S, Trisuwan K, Pyne SG, Ritthiwigrom T. 2014. Carbazole alkaloids and coumarins from the roots of Clausena guillauminii. Phytochem Lett. 9:113-116.

Bajaj S, Khan A. 2012. Mini Review Antioxidants and diabetes. Indian J Endocrinol Metab. 16: 67-71.

Cahyani RT, Purwaningsih S. 2015. Antidiabetic potential and secondary metabolites screening of mangrove gastropod Cerithidea obtusa. J Coast Life Med. 3:356-360.

Chakthong S, Bindulem N, Raknai S, Yodwaree S, Kaewsanee S, Kanjana-Opas A. 2016. Carbazole-pyranocoumarin conjugate and two carbazole alkaloids from the stems of Clausena excavata. Nat Prod Res. 30(15):1690-1697.

Deepak KGK, Nageswara RRN, Surekha C. 2014. Role of antidiabetic compounds on glucose metabolism? A special focus on medicinal plant: Salacia sps. Med Chem. 4:373-381.

Damsud T, Chanwun T, Kaewpiboon C. 2017. Antidiabetic agents with $\alpha$-glucosidase inhibition and antioxidant capacity from the shoots of Clausena cambodiana Guill. Int J Agric Technol. 13:449-456.

Gothai S, Ganesan P, Park SY, Fakurazi S, Choi DK, Arulselvan P. 2016. Natural phyto-bioactive compounds for the treatment of type 2 diabetes: Inflammation as a target. Nutrients. 8:1-28.

Ito C, Itoigawa M, Katsuno S, Omura M, Tokuda H, Nishino H, Furukawa H. 2000. Chemical constituents of Clausena excavata: Isolation and structure elucidation of novel furanonecoumarins with inhibitory effects for tumor-promotion. J Nat Prod. 63(9):1218-1224.

Kumar R, Saha A, Saha D. 2012. A new antifungal coumarin from Clausena excavata. Fitoterapia. 83(1):230-233.

Liu Y, Wen Q, Hu S, Ma Y, Jiang Z, Tang J. 2018. Furanocoumarins with potential antiproliferative activities from Clausena lenis. Nat Prod Res. 6419:1-7.

Munhoz ACM, Frode TS. 2018. Isolated compounds from natural products with potential antidiabetic activity - a systematic review. Curr Diabetes Rev. 14:1-28.

Ma Y, Zhang C, Zhao W, Shi S, He D, Zhang P. 2017. Bioactive furanocoumarins from the stems and leaves of Clausena hainanensis. Nat Prod Res. 6419:1-6.

Ramadhan R, Phuwapraisirisan P. 2015. New arylalkanones from Horsfieldia macrobotrys, effective antidiabetic agents concomitantly inhibiting $\alpha$-glucosidase and free radicals. Bioorganic Med Chem Lett. 25(20):4529-4533.

Sripisut T, Cheenpracha S, Ritthiwigrom T, Prawat U, Laphookhieo S. 2012. Chemical constituents from the roots of Clausena excavata and their cytotoxicity. Rec Nat Prod. 6:386-389.

Sindhi V, Gupta V, Sharma K, Bhatnagar S, Kumari R, Dhaka N. 2013. Potential applications of antioxidants - a review. J Pharm Res. 7:828-835.

Takemura Y, Kawaguchi H, Maki S, Ju-Ichi M, Omura M, Ito C, Furukawa H. 1996. Studies on the constituents of Yalaha. Structures of a new acridone and two new coumarins. Chem Pharm Bull. 44(4):804-809.

Taufiq-Yap YH, Peh TH, Ee GCL, et al. 2007. A new cytotoxic carbazole alkaloid from Clausena excavata. Nat Prod Res. 21:310-313.

Wu TS, Huang SC, Wu PL, Kuoh CS. 1999. Alkaloidal and other constituents from the root bark of Clausena excavata. Phytochemistry. 52(3):523-527. 


\section{SJR}

Home

\section{Natural Product Research}

Country United Kingdom - ㅍII SIR Ranking of United Kingdom

\section{Subject Area and Category \\ Agricultural and Biological Sciences \\ Plant Science}

Publisher

Publication type

ISSN

Coverage

Scope

? Biochemistry

Chemistry

Analytical Chemistry

Organic Chemistry

Taylor \& Francis

Journals

14786419

2003-ongoing

Homepage
Biochemistry, Genetics and Molecular Biology

The aim of Natural Product Research is to publish important contributions in the field of natural product chemistry. The journal covers all aspects of research in the chemistry and biochemistry of naturally occurring compounds. The communications include coverage of work on natural substances of land and sea and of plants, microbes and animals.

Discussions of structure elucidation, synthesis and experimental biosynthesis of natural products as well as developments of methods in these areas are welcomed in the journal. Finally, research papers in fields on the chemistry-biology boundary, eg. fermentation chemistry, plant tissue culture investigations etc., are accepted into the journal.

Join the conversation about this journal

\section{Quartiles}

Analytical Chemistry

Biochemistry

Organic Chemistry

Plant Science

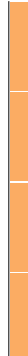

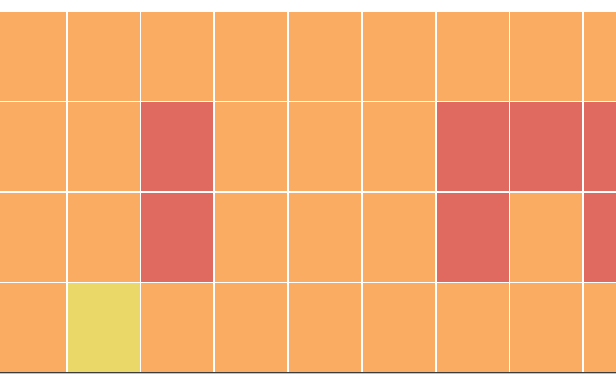

1999
2001
2005

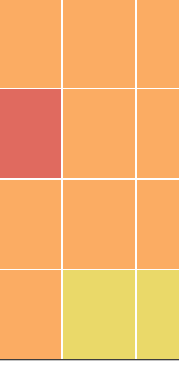

2009

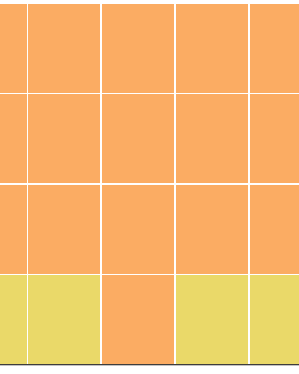

2011
2013

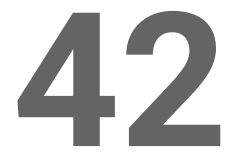

$\mathrm{H}$ Index 


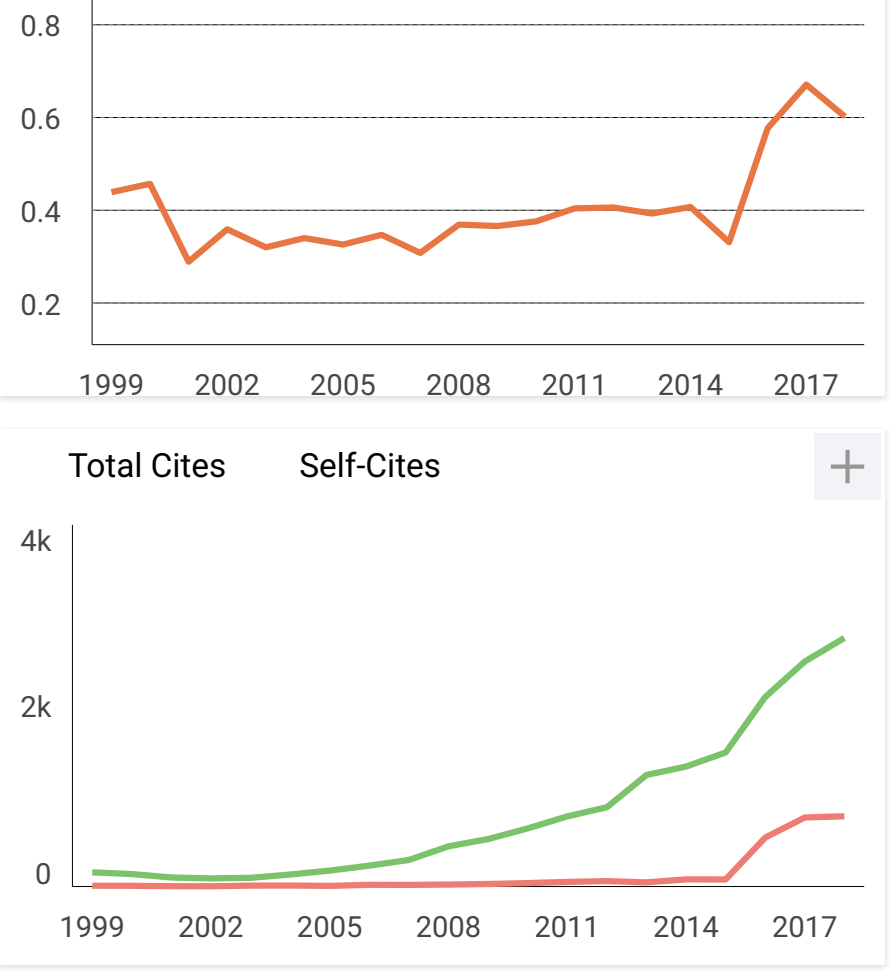

External Cites per Doc Cites per Doc

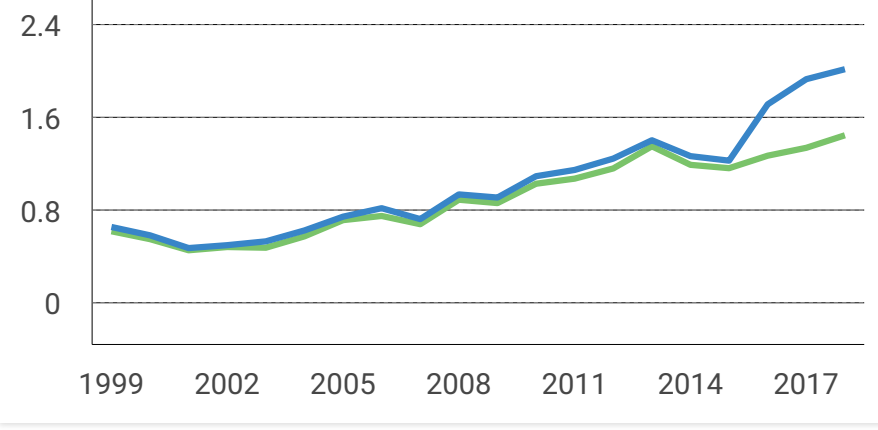

Citable documents Non-citable documents $\quad+$

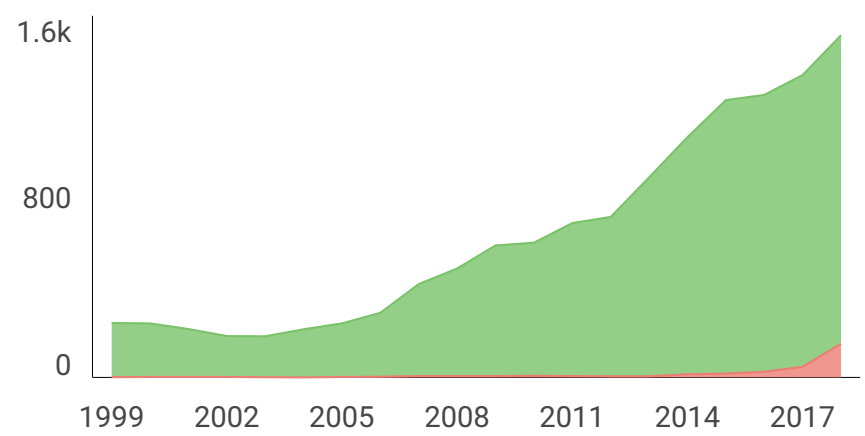

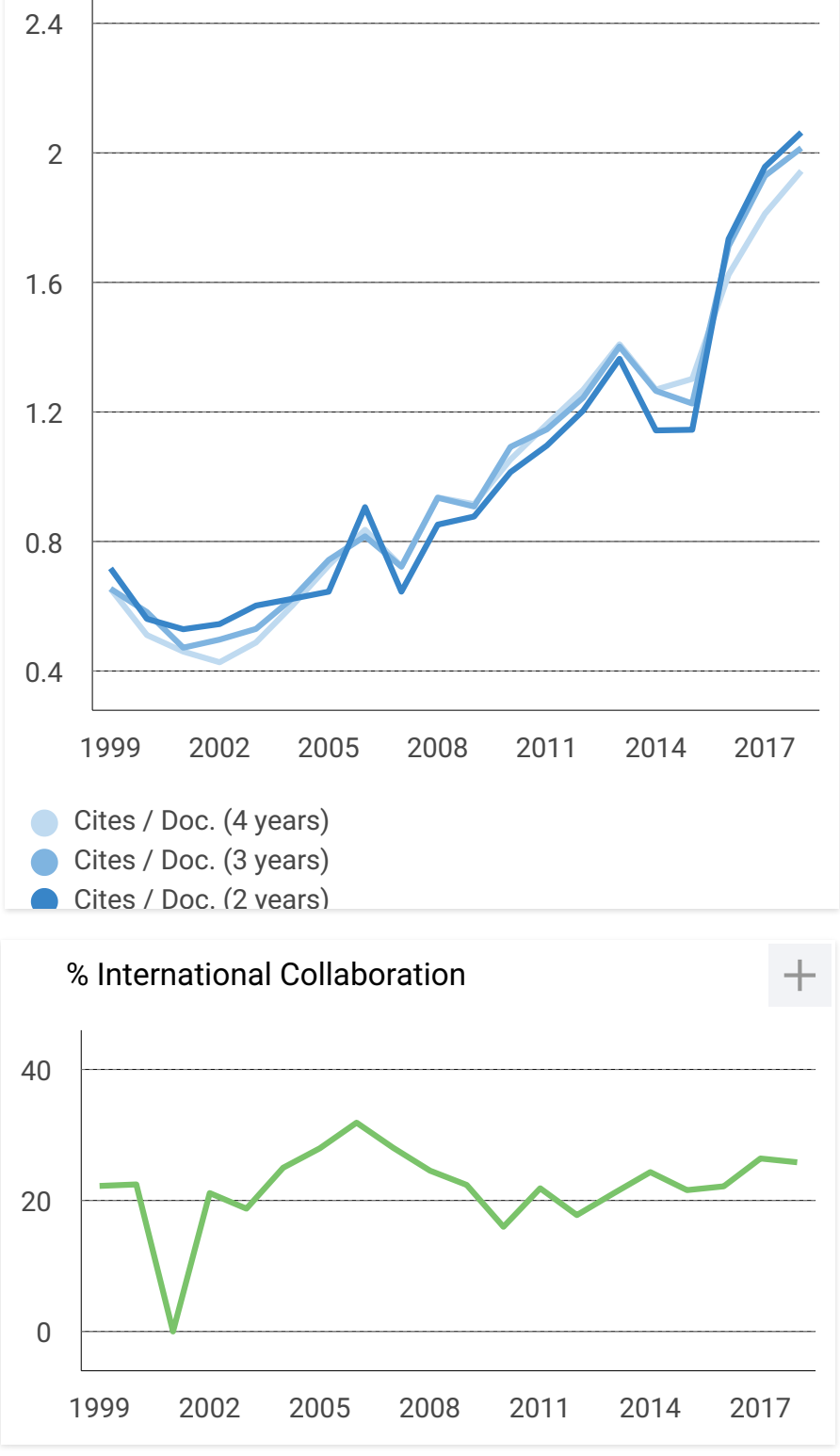

Cited documents Uncited documents $\quad+$

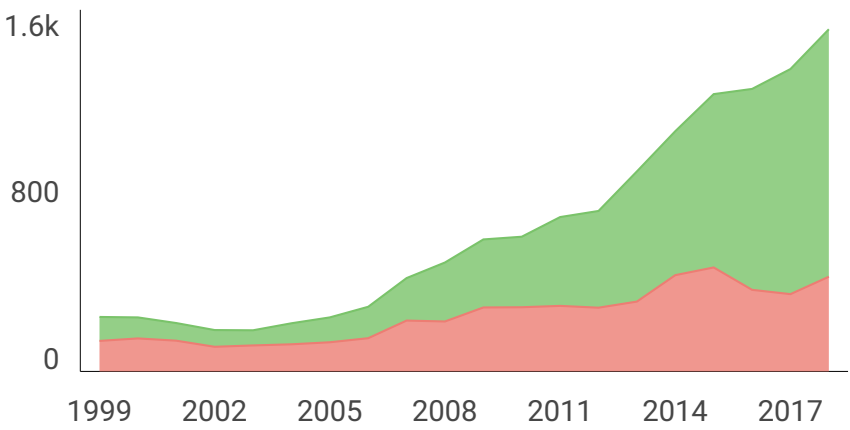




\section{Leave a comment}

Name

\section{Email}

(will not be published)

I'm not a robot

Submit

The users of Scimago Journal \& Country Rank have the possibility to dialogue through comments linked to a specific journal. The purpose is to have a forum in which general doubts about the processes of publication in the journal, experiences and other issues derived from the publication of papers are resolved. For topics on particular articles, maintain the dialogue through the usual channels with your editor.

Developed by:

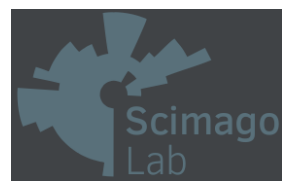

Follow us on @ScimagoJR
Powered by:

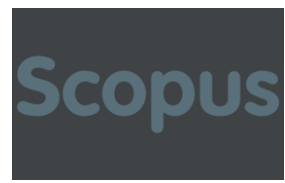


Journal

\section{Natural Product Research > \\ Formerly Natural Product Letters}

\section{This journal}

\section{Editorial board}

\section{Editor-in-Chief:}

Armandodoriano Bianco - Dipartimento di Chimica, Università degli Studi di Roma "La Sapienza", Piazzale Aldo Moro 5, 00185 Roma, Italy

\section{Editors:}

Søren Rosendal Jensen - DTU Chemistry, Department of Chemistry, Emeriti, Organic Chemistry, DK-2820 Lyngby, Denmark

Marcello Nicoletti - Facolta di Farmacia e Medicina, Università degli Studi di Roma "La Sapienza", Piazzale Aldo Moro 5, 00185 Roma, Italy

\section{Editorial Office:}

Dr Ilaria Serafini - Dipartimento di Chimica, Università degli Studi di Roma "La Sapienza", Piazzale Aldo Moro 5, 00185 Roma, Italy Alessandro Venditti - Dipartimento di Chimica, Università degli Studi di Roma "La Sapienza", Piazzale Aldo Moro 5, 00185 Roma, Italy

\section{Associate Editors:}

D. J. Aitken - Institute of Molecular Sciences of Orsay, France

B Charlwood - Universidade Federal de Alagoas, Campus Universitario, Brazil

P. Ciminiello - Università di Napoli "Federico II", Italy 
L. N. Mander - The Australian National University, Canberra, Australia

K. Mori- University of Tokyo, Japan

I. Ninomiya - Kobe Pharmaceutical University, Kobe, Japan

R. J. Parry - Rice University, Houston, Texas

O. Sterner - Lund University, Sweden

J Stöckigt - Johannes Guttenberg University, Germany

\section{Editorial Board:}

G. Appendino - Italy

Y. Asakawa - Japan

M. Ballero - Italy

R. Bernini - Italy

E. Block - USA

E. Brasili - Italy

M. Bruno - Italy

H. Budzikiewicz - Germany

S. D. Burke - USA

L. Castedo - Spain

N. Cicero - Italy

G. Cimino - Italy

G. A. Cordell - USA

P. Cortis - Italy

B. Danieli - Italy

S. Danishefsky - USA

V. De Feo - Italy

I. Fleming - UK

B. Fraser - Reid - USA

C. Frezza -Italy

F. R. Grippaudo - Italy

L. Gunatilaka - USA

G. M. Halpern - China

S. Hanessian - Canada

J. R. Hanson - UK

K. Hostettmann - Switzerland

M. Isobe - Japan

D. Kinghorn - USA

J. Lehn - France 
P. W. Le Quesne - USA

S. V. Ley - UK

Y. Liu - China

P. D. Magnus - USA

K. Nakanishi - USA

R. Noyori - Japan

S. Persechino - Italy

J. M. Pezzuto - USA

G. A. M. Pintore - Italy

F. Poli - Italy

E. Rodriguez - USA

D. S. Rycroft - UK

C. Sanna - Italy

F. Sciubba - Italy

B. Sener - Turkey

M. Serafini - Italy

L. -Y. Sheen - Taiwan

G. Solladie - France

D. Spitzner - Germany

G. Topcu - Turkey

E. Tramontano - Italy

B. M. Trost - USA

R. Verpoorte - Netherlands

W. Voelter - Germany

H. Wagner - Germany

P. G. Waterman - Australia

J. D. White - USA

K. R. Zeller - Germany 


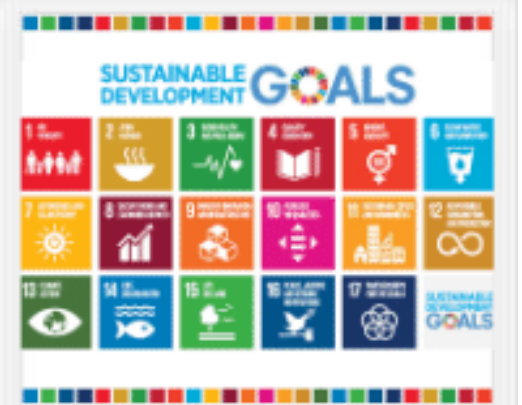

Register for 50 free articles

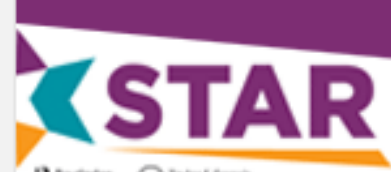

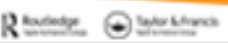

Information for

Authors

Editors

Librarians

Societies

Help and info

Help \& contact

Newsroom

Commercial services

All journals
Open access

Overview

Open journals

Open Select

Cogent OA

Keep up to date

Register to receive personalised research and resources by email

$\nabla$ sig

Sign me up

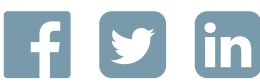

Toube

Copyright () 2019 Informa UK Limited Privacy policy \& cookies Terms \& conditions Accessibility 


\section{Natural Product Research - Manuscript ID GNPL-2018-3087.R2}

1 message

Natural Product Research <onbehalfof@manuscriptcentral.com>

Mon, Feb 4, 2019 at 3:23 PM

Reply-To: alessandro.venditti@gmail.com

To: nanik-s-a@fst.unair.ac.id, naniksa2000@gmail.com

Cc: tin.myo.thant-2017@fst.unair.ac.id, nanik-s-a@fst.unair.ac.id, naniksa2000@gmail.com, alfinda-n-k@fst.unair.ac.id, rico.ramadhan@fst.unair.ac.id, preecha.p@chula.ac.th, ytakaya@meijo-u.ac.jp

${ }^{\star * \star \star \star \star \star}$ This is an automated email generated by the Natural Product Research ScholarOne Manuscripts site ${ }^{\star \star \star \star \star \star *}$

\section{4-Feb-2019}

Dear Dr Aminah:

Your manuscript entitled "A new pyrano coumarin from Clausena excavata roots displaying dual inhibition against aglucosidase and free radical" has been successfully submitted online and is presently being given full consideration for publication in Natural Product Research.

Your manuscript ID is GNPL-2018-3087.R2.

Please mention the above manuscript ID in all future correspondence or when calling the office for questions. If there are any changes in your street address or e-mail address, please log in to Manuscript Central at https://mc.manuscriptcentral. com/gnpl and edit your user information as appropriate.

You can also view the status of your manuscript at any time by checking your Author Centre after logging in to https://mc.manuscriptcentral.com/gnpl.

Thank you for submitting your manuscript to Natural Product Research.

Sincerely,

Natural Product Research Editorial Office 


\section{GNPL-2018-3087.R2 Assigned to Editor}

1 message

Natural Product Research <onbehalfof@manuscriptcentral.com>

Wed, Feb 6, 2019 at 4:18 AM

Reply-To: alessandro.venditti@gmail.com

To: nanik-s-a@fst.unair.ac.id, naniksa2000@gmail.com

05-Feb-2019

\section{Dear Dr Aminah,}

This is a message to confirm that your revised manuscript GNPL-2018-3087.R2 "A new pyrano coumarin from Clausena excavata roots displaying dual inhibition against $\alpha$-glucosidase and free radical" is being considered for publication in Natural Product Research and has been assigned to Professor Armandodoriano Bianco to serve as the editor.

Once Professor Bianco is able to make a decision on your revised paper, we will contact you with a decision letter as soon as possible.

Thank you for revising your work and we look forward to bringing you a decision on your manuscript as soon as possible.

\section{Best regards,}

Dr Alessandro Venditti

Editorial Office | Natural Product Research

https://mc.manuscriptcentral.com/gnpl

alessandro.venditti@gmail.com 


\section{Natural Product Research - Decision on Manuscript ID GNPL-2018-3087.R1}

2 messages

Natural Product Research <onbehalfof@manuscriptcentral.com>

Thu, Jan 31, 2019 at 11:31 PM

Reply-To: armandodoriano.bianco@uniroma1.it

To: nanik-s-a@fst.unair.ac.id, naniksa2000@gmail.com

31-Jan-2019

Dear Dr Aminah,

Thank you for resubmitting your paper to Natural Product Research.

I am delighted to inform you that your paper has now been accepted by the Natural Product Research, subject to revision along the lines suggested below, and the reviewer comments at the end of this letter.

We will be in touch with you again with further details closer to the date of publication.

I would be grateful if you could now provide a final paper following (Journal) guidelines, with a Title page containing authors affiliation and e-mail address (page 1), followed by Abstract and Key Words (page 2), and full text, all in the same document. Only tables and figures are to be included as a separate document.

To provide your final version, please click on the link below:

${ }^{* * *}$ PLEASE NOTE: This is a two-step process. After clicking on the link, you will be directed to a webpage to confirm. ${ }^{* * *}$ https://mc.manuscriptcentral.com/gnpl?URL_MASK=8843542762b542e78343e4c04eaaa453

This will direct you to the first page of your revised manuscript. This link will remain active until you have submitted your revised manuscript. If you begin a revision and intend to finish it at a later time, please note that your draft will appear in the "Revised Manuscripts in Draft" queue in your Author Centre.

IMPORTANT: Your original files are available to you when you upload your revised manuscript. Please delete any redundant files before completing the submission.

Because we aim for the timely publication of manuscripts submitted to Natural Product Research, please upload your revised manuscript as soon as possible and before 02-Mar-2019.

Once again, thank you for submitting your manuscript to Natural Product Research and I look forward to receiving your revision.

Sincerely,

Professor Bianco

Editor-in-Chief, Natural Product Research

armandodoriano.bianco@uniroma1.it

Reviewer(s)' Comments to Author:

Editorial Office:

The figures/tables which will appear in the main document should be submitted in single copy as individual files provided with captions, and not embedded in the main document.

\section{Reviewer: 1}

Comments to the Author

It can be accepted for publishion in present form.

nanik siti aminah <nanik-s-a@fst.unair.ac.id>

Fri, Feb 1, 2019 at 3:40 AM

To: tin myo <tin.myo.thant-2017@fst.unair.ac.id>, ramadhan Rico <rico.ramadhan@fst.unair.ac.id>, alfinda novi kristanti <alfinda-n-k@fst.unair.ac.id>

Forwarded message -

From: Natural Product Research <onbehalfof@manuscriptcentral.com>

Date: Thu, 31 Jan 2019, 23:31

Subject: Natural Product Research - Decision on Manuscript ID GNPL-2018-3087.R1

To: <nanik-s-a@fst.unair.ac.id>, <naniksa2000@gmail.com>

31-Jan-2019

Dear Dr Aminah,

Thank you for resubmitting your paper to Natural Product Research. 
I am delighted to inform you that your paper has now been accepted by the Natural Product Research, subject to revision along the lines suggested below, and the reviewer comments at the end of this letter.

We will be in touch with you again with further details closer to the date of publication.

I would be grateful if you could now provide a final paper following (Journal) guidelines, with a Title page containing authors affiliation and e-mail address (page 1), followed by Abstract and Key Words (page 2), and full text, all in the same document. Only tables and figures are to be included as a separate document.

To provide your final version, please click on the link below:

${ }^{* * *}$ PLEASE NOTE: This is a two-step process. After clicking on the link, you will be directed to a webpage to confirm. ${ }^{* * *}$ https://mc.manuscriptcentral.com/gnpl?URL_MASK=8843542762b542e78343e4c04eaaa453

This will direct you to the first page of your revised manuscript. This link will remain active until you have submitted your revised manuscript. If you begin a revision and intend to finish it at a later time, please note that your draft will appear in the "Revised Manuscripts in Draft" queue in your Author Centre.

IMPORTANT: Your original files are available to you when you upload your revised manuscript. Please delete any redundant files before completing the submission.

Because we aim for the timely publication of manuscripts submitted to Natural Product Research, please upload your revised manuscript as soon as possible and before 02-Mar-2019.

Once again, thank you for submitting your manuscript to Natural Product Research and I look forward to receiving your revision.

Sincerely,

Professor Bianco

Editor-in-Chief, Natural Product Research

armandodoriano.bianco@uniroma1.it

\section{Reviewer(s)' Comments to Author:}

\section{Editorial Office:}

The figures/tables which will appear in the main document should be submitted in single copy as individual files provided with captions, and not embedded in the main document.

\section{Reviewer: 1}

Comments to the Author

It can be accepted for publishion in present form. 
Natural Product Research Taylor \& Francis

\begin{tabular}{l|l|l|l|l|l|}
\hline * Home & Author & Review
\end{tabular}

Author Dashboard

\section{Author Dashboard}

1 Submitted Manuscripts

4 Manuscripts with Decisions

Start New Submission

Legacy Instructions

5 Most Recent E-mails

English Language Editing Service

\section{Manuscripts with Decisions}




(C) Clarivate Analytics | (c) ScholarOne, Inc., 2019. All Rights Reserved.

ScholarOne Manuscripts and ScholarOne are registered trademarks of ScholarOne, Inc.

ScholarOne Manuscripts Patents \#7,257,767 and \#7,263,655.

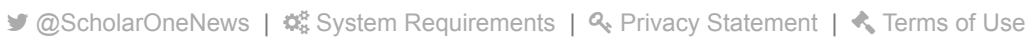


Natural Product Research Taylor \& Francis

\begin{tabular}{l|l|l|l|l|l|}
\hline * Home & Author & Review
\end{tabular}

Author Dashboard

\section{Author Dashboard}

1 Submitted Manuscripts

4 Manuscripts with Decisions

Start New Submission

Legacy Instructions

5 Most Recent E-mails

English Language Editing Service

\section{Manuscripts with Decisions}

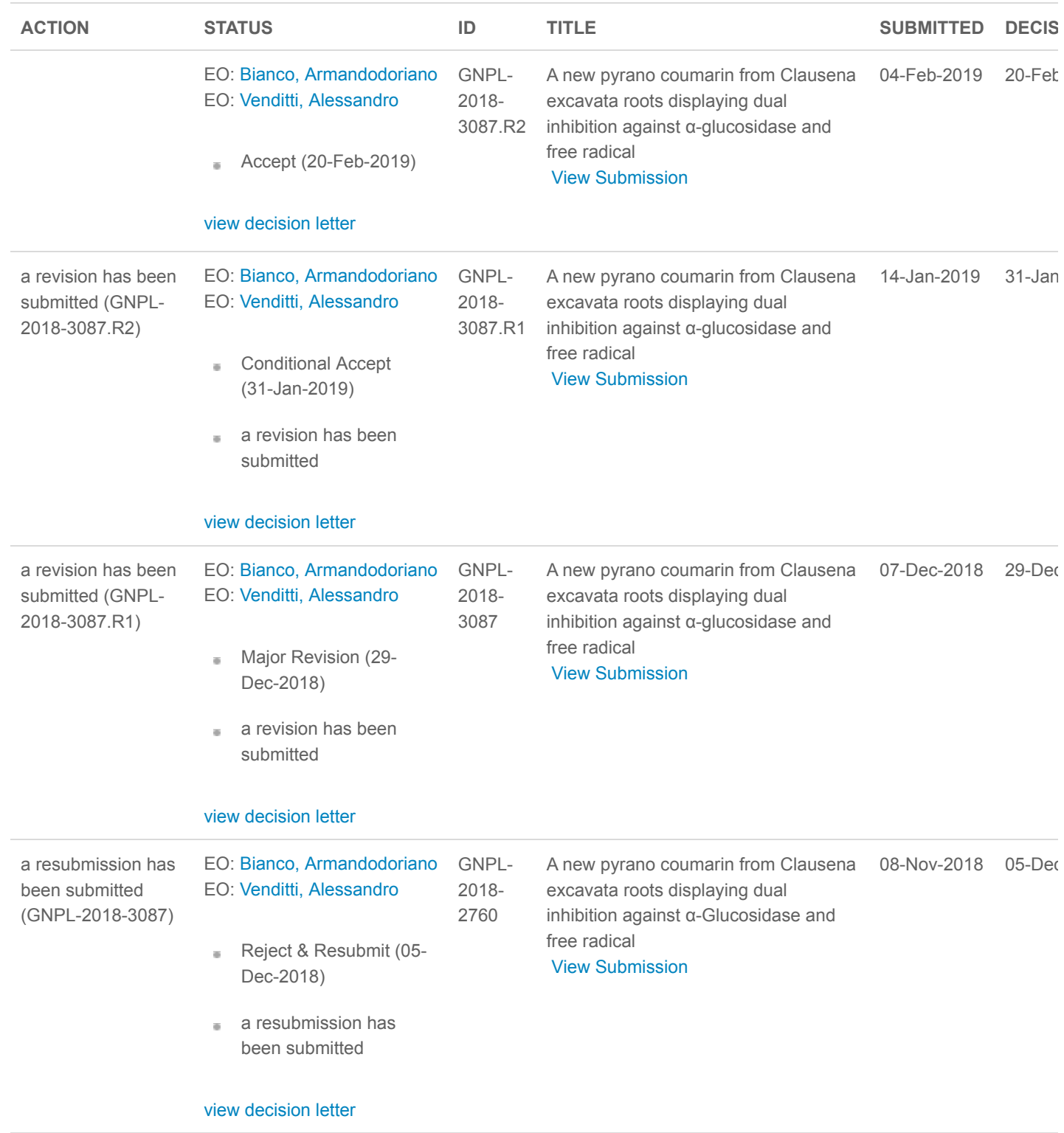


(C) Clarivate Analytics | (c) ScholarOne, Inc., 2019. All Rights Reserved.

ScholarOne Manuscripts and ScholarOne are registered trademarks of ScholarOne, Inc.

ScholarOne Manuscripts Patents \#7,257,767 and \#7,263,655.

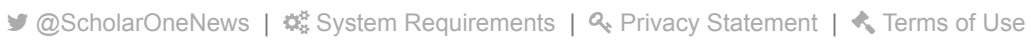

